\title{
Metals and Acid Volatile Sulfide in Sediment Cores from the Sergipe River Estuary, Northeast, Brazil
}

\author{
José do Patrocínio H. Alves, Elisângela de Andrade Passos and Carlos A. B. Garcia* \\ Laboratório de Química Analítica Ambiental, Departamento de Química, Universidade Federal de Sergipe, \\ 49.100-000 São Cristóvão-SE, Brazil
}

\begin{abstract}
Foram estudados o sulfeto volatilizado em meio ácido (AVS), os metais simultaneamente extraídos (SEM) e os metais em sítios de sedimentos do Estuário do Rio Sergipe, Brasil. As concentrações de AVS e SEM foram, em geral, maiores nos sedimentos dos sítios situados nas áreas que recebem maior aporte antrópico devido à poluição urbana. Nesses sítios, o sulfeto parece ser a principal fase de ligação para os metais. No sítio do sedimento situado na área de maior influência marinha, as fases mais importantes de ligação para os metais parecem estar associadas à matéria orgânica e aos carbonatos. Os perfis de AVS permitiram identificar dois tipos de processos de sedimentação no estuário. Em todos os sítios, as relações SEM/AVS foram muito menores do que 1.
\end{abstract}

Acid volatile sulfide (AVS), simultaneously extracted metals (SEM) and metals were studied in sediment cores from the Sergipe River Estuary, Brazil. AVS and SEM concentrations were, in general, higher in the core sediments from areas which receive a higher anthropic contribution due to urban pollution. In these cores, the sulfide seemed to be the main connection for the metals. In the core obtained from the area of major marine influence, the most important binding phases for the metals seemed to be associated with organic matter and carbonates. The AVS profiles allow identification of two types of sedimentation processes in the estuary. In all cores $\mathrm{SEM} / \mathrm{AVS}$ ratios were much lower than 1.

Keywords: sediments, heavy metals, acid volatile sulfide, simultaneously extracted metals

\section{Introduction}

Sediments are formed by deposition of layers of fine particulate matter onto the beds of rivers, lakes, estuaries and oceans. They function as an important compartment of the aquatic ecosystem and serve as habitat of many species of organisms. They comprise mineral phases of varied sizes, including clay, silt and sand, mixed with organic matter. An important characteristic of sediment is its capacity to serve as a reservoir for trace metals introduced into the aquatic environment by natural geochemical processes and anthropogenic activities. ${ }^{1,2}$

Di Toro et al. ${ }^{3}$ suggest that the concentration of metal in the pore water can be controlled by acid volatile sulfide (AVS), via the formation of insoluble metal sulfide complexes. Several laboratory studies have demonstrated the AVS influence over the bioavailability and acute

*e-mail: cgarcia@ufs.br toxicity of divalent metals in aquatic sediments. ${ }^{2,46}$ When the sediments show excess of AVS in relation to the simultaneously extracted metals $(\mathrm{SEM} / \mathrm{AVS}<1)$ the pore water metal concentrations are considered to be low and non-toxic. ${ }^{7}$ Some research has shown a significant bioaccumulation for sediments with SEM/AVS $<1 .{ }^{8,9}$

The sulfide level in sediments is a function of the production rate of sulfide by reduction of sulfate, and the loss rate of sulfide by oxidation reactions and diffusion processes. ${ }^{10,11}$

Berner describes diagenetic sulfide formation as a function of porosity, sediment density, mixing intensity, organic matter supply, $\mathrm{SO}_{4}$ in pore water diffusion coefficient, rate of $\mathrm{SO}_{4}$ reduction and $\mathrm{SO}_{4}$ concentration at the water-sediment interface. ${ }^{12}$

Consequently, AVS profiles can provide information describing the depositional process of the sediment in each core. Some studies of this nature have been carried out. ${ }^{13,14}$ Oehm et al..$^{15}$ concluded that only one core cannot completely represent sedimentation in the environment, 
due to spatial differences in the supply of reactive organic matter. Some studies have been carried out in coastal sediments.

In the present study, three sediment cores from different locations of the Sergipe River Estuary were analyzed with the purpose of investigating the AVS, SEM, total heavy metals and the relationships of these profiles with the dynamics of the estuarine environment.

\section{Materials and Methods}

Study area

The Sergipe River basin is located in the State of Sergipe, in the Northeast of Brazil. It covers an area of $3673 \mathrm{~km}^{2}$ and has an average flow of $560,000 \mathrm{~m}^{3}$ day $^{-1}$ in the rainy season and $70,000 \mathrm{~m}^{3}$ day $^{-1}$ in the dry season. The river runs about $210 \mathrm{~km}$ from its spring to its mouth into the Atlantic Ocean in the city of Aracaju, Capital of the State. ${ }^{16}$

The study area has an extension of $15 \mathrm{~km}$ covering the lower part of the Sergipe River Estuary and the estuarine region of the Sal and Poxim Rivers (Figure 1). Within this area the cities of Aracaju, Nossa Senhora do Socorro, São Cristovao and Barra dos Coqueiros are located, which together make up an extension of 859.3 $\mathrm{km}^{2}$ and are home to $37.9 \%$ of the population of the State. The estuary directly receives industrial sewage, dominated by emissions from food, plastic, textile, ceramic and metallurgical industries. Domestic sewage waste waters are also released into the estuary, in natura, from the neighboring cities, and as the effluent from sewage treatment facilities in Aracaju.

The estuarine region is characterized by a well-mixed water column, with a circulation standard mainly dominated by the tidal currents. Lately, the estuary has shown hypoxic conditions and characteristics of an environment in process of eutrophication. The more impacted areas are those of the Sal and Poxim Rivers, where the oxygen dissolved in water has shown levels below $3.00 \mathrm{mg} \mathrm{L}^{-1}$, at some locations reaching values close to zero. ${ }^{17}$

\section{Sampling}

In the present study, three sediment cores were collected in September 2004, in the estuarine region formed by the Sal River (core 1; $10^{\circ} 51^{\prime} 51^{\prime \prime} \mathrm{S}, 37^{\circ} 05^{\prime} 01^{\prime \prime}$ W), Sergipe River (core 8; $10^{\circ} 54^{\prime} 09^{\prime \prime} \mathrm{S}, 37^{\circ} 02^{\prime} 25^{\prime \prime} \mathrm{W}$ ) and Poxim River (core 19; $10^{\circ} 56^{\prime} 24^{\prime \prime} \mathrm{S}, 37^{\circ} 05^{\prime} 16^{\prime \prime} \mathrm{W}$ ). The location of the sampling sites is indicated in Figure 1.

The sediments were taken with a core sampler of cellulose acetate-butyrate pipe type, with precaution to prevent destruction of the core, using non-metallic devices to avoid contamination. Each sediment core was fieldsliced at $5 \mathrm{~cm}$ interval, as it was expelled from the core sampler. The samples were rapidly stored in closed plastic bags with ice to minimize oxidation. The samples to be

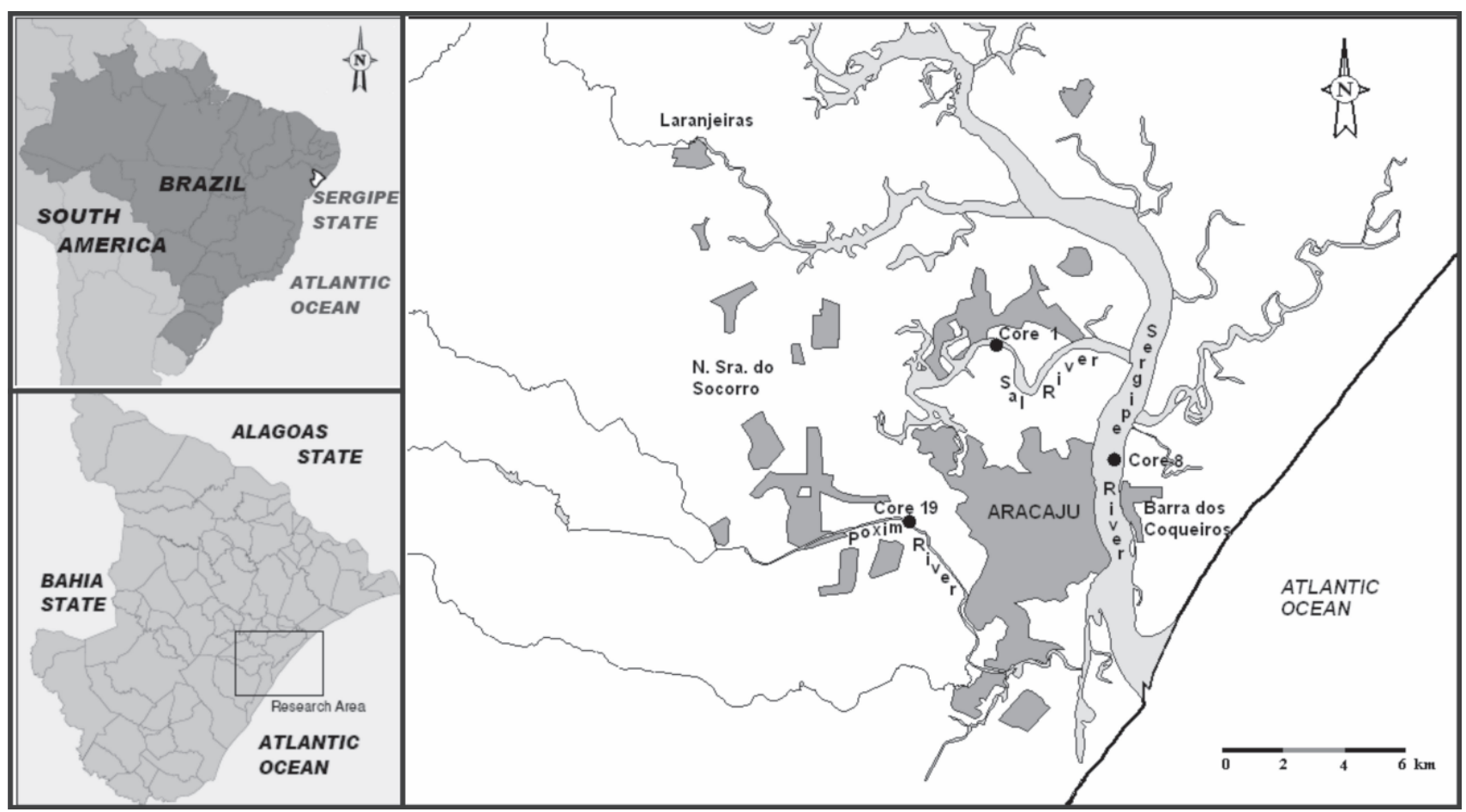

Figure 1. Location of sampling sites in the Sergipe River Estuary, Northeast Brazil. 
used for AVS determination were, as recommended in the literature, ${ }^{18-20}$ maintained in the refrigerator at $4{ }^{\circ} \mathrm{C}$ and analyzed within a maximum period of four days after collection. The samples intended for metal determination were immediately dried in a forced air circulation oven at $60{ }^{\circ} \mathrm{C}$ for $72 \mathrm{~h}$ (until reaching a constant mass) and then were homogenized by crushing in a porcelain mortar until a fine powder was obtained. Following this, they were sealed in previously cleaned glass flasks until analyzed.

\section{Chemical analyses}

The procedure adopted for determining AVS and SEM was based on the methodology described by Di Toro et al. ${ }^{3}$

About $12 \mathrm{~g}$ of wet sediment at room temperature were transferred to a closed reaction vessel, connected to a trapping vessel containing $20 \mathrm{~mL}$ of $0.1 \mathrm{~mol} \mathrm{~L}^{-1} \mathrm{NaOH}$ solution. To the wet sediment sample was added $30 \mathrm{~mL}$ of $0.5 \mathrm{~mol} \mathrm{~L}^{-1} \mathrm{HCl}$, forming $\mathrm{H}_{2} \mathrm{~S}$ which was subsequently collected in the $\mathrm{NaOH}$ solution by purging with $\mathrm{N}_{2}$ for 40 minutes. The dissolved sulfide in the $\mathrm{NaOH}$ solution was potentiometrically titrated in an automatic system (Radiometer TM 865) with a $0.03 \mathrm{~mol} \mathrm{~L}^{-1} \mathrm{AgNO}_{3}$ solution using a sulfide selective ion electrode with $\mathrm{Ag} / \mathrm{AgCl}$ reference electrode.

$\mathrm{HCl}$ and sediment mixture in the reaction vessel were separated by centrifugation and the concentrations of the simultaneously extracted metals (SEM) in the solution were determined by flame or graphite furnace atomic absorption spectrometry (FAAS/GFAAS) (Shimadzu AA-6800).

For evaluating the efficiency of the AVS extraction method, a standard $\mathrm{Na}_{2} \mathrm{~S}\left(79.18 \mathrm{mg} \mathrm{L}^{-1}\right)$ solution was used, obtaining in three replications an average recovery of $93 \pm 3 \%$. The results of the measurements in duplicate of the AVS showed an analytical precision of less than $10 \%$. In the extraction process for AVS determination, blanks with 0.5 mol L ${ }^{-1} \mathrm{HCl}$ solution were prepared similarly to the samples, and concentrations in the blanks were negligible for all metals measured in the SEM determination.

Sediment samples $(0.5 \mathrm{~g})$, dried to constant mass at $60{ }^{\circ} \mathrm{C}$, were digested in closed Teflon vessels using a mixture of concentrated $\mathrm{HNO}_{3}(2 \mathrm{~mL}), \mathrm{HCl}(1 \mathrm{~mL})$ and $\mathrm{HF}(4 \mathrm{~mL})$, at $140{ }^{\circ} \mathrm{C}$ for 2 hours on a heating block. After digestion, the Teflon vessels were opened and maintained at $210^{\circ} \mathrm{C}$ until complete dryness. The residue was dissolved in $10 \mathrm{~mL}$ of $0.5 \mathrm{~mol} \mathrm{~L}^{-1} \mathrm{HCl}$ solution and the final volume made up to $50 \mathrm{~mL}$. The solutions were stored in polyethylene flasks for later determination of the metals by flame or graphite furnace atomic absorption spectrometry. Reagent blanks were prepared similarly to the samples, and the following certified sediment standards were analyzed for quality control purposes: LKSD-1 CCNRP/Canada lake sediment; NCS DC 75304/China river sediment; NCS DC 78301/China marine sediment. The results showed that there was no significant contamination and that the recovery of the heavy metals in the reference materials was in the range 92-106\%.

The measurement of the total carbon content in the samples was carried out using an Elemental Analyzer (NCHS-O, Flash EA 1112) with combustion at $900{ }^{\circ} \mathrm{C}$. The organic carbon content was calculated from the difference of the carbon values measured before and after calcination of the samples at $550{ }^{\circ} \mathrm{C}$ for 1 hour. For quality control purposes a certified Lake Sediment standard (LKSD-1 CCNRP/Canada) was analyzed together with the samples, obtaining in three replications an average recovery of $96.3 \pm 4.2 \%$.

Principal Components Analysis (PCA) and calculations of correlation coefficients were carried out using the program "Statistica for Windows Version 6.0".

\section{Results and Discussion}

\section{Characteristics of the sediments}

The chemical characteristics of the sediments in the three cores are shown in Table 1. The method of Principal Components Analysis was applied to the sets of chemical parameters measured in the fractions of the cores with the objective of detecting a possible grouping between them. PCA is a non-parametric method of classification, employed to reduce the dimensionality of a data set while attempting to preserve the relationships present in the original data. The method consists in applying the multivariate statistical analysis on the results obtained, considering each fraction as an object (5 fractions of core 1; 8 of core 8 and 8 of core 19) and the parameters measured as variables (12 variables). With the purpose of assuring that the relative influences of the different variables on the model were independent of the units of these variables, the columns of the data matrix were selfassigned so that the new variables had zero average and unit variance.

Two principal components were extracted, together representing $76.8 \%$ of the total variance $\left(\mathrm{t}_{1} 57.0 \% ; \mathrm{t}_{2}\right.$ $19.8 \%$ ). Based on the weight of the contribution of each variable in the PCA (Table 2) it can be seen that $\mathrm{Cu}, \mathrm{Cd}$, $\mathrm{Ni}, \mathrm{Zn}, \mathrm{Cr}, \mathrm{Al}$ and $\mathrm{C}_{\text {org }}$ are strongly associated with component $\mathrm{t}_{1}$ and $\mathrm{Mn}$ and $\mathrm{Pb}$ with component $\mathrm{t}_{2}$.

The location of each fraction on the coordinate plan formed by the two components $t_{1}$ and $t_{2}$ is shown in Figure 
Table 1. Metals (total concentration in dry sediment), AVS, SEM and $\mathrm{C}_{\text {org }}$ of the sediment cores in the estuarine region formed by the Rivers: Sal (core 1), Sergipe (core 8) and Poxim (core 19)

\begin{tabular}{|c|c|c|c|c|c|c|c|c|c|c|c|c|c|}
\hline Segment & $\begin{array}{l}\text { Depth } \\
\mathrm{cm}\end{array}$ & $\begin{array}{c}\text { AVS } \\
\left(\mu \mathrm{mol} \mathrm{g}{ }^{-1}\right)\end{array}$ & $\begin{array}{c}\text { SMEM } \\
\left(\mu \mathrm{mol} \mathrm{g}{ }^{-1}\right)\end{array}$ & $\begin{array}{c}\mathrm{Cd} \\
\left(\mu \mathrm{g} \mathrm{g}^{-1}\right)\end{array}$ & $\begin{array}{c}\mathrm{Cu} \\
\left(\mu \mathrm{g} \mathrm{g}^{-1}\right)\end{array}$ & $\begin{array}{c}\mathrm{Ni} \\
\left(\mu \mathrm{g} \mathrm{g}^{-1}\right)\end{array}$ & $\begin{array}{c}\mathrm{Pb} \\
\left(\mu \mathrm{g} \mathrm{g}^{-1}\right)\end{array}$ & $\begin{array}{c}\mathrm{Zn} \\
\left(\mu \mathrm{g} \mathrm{g}^{-1}\right)\end{array}$ & $\begin{array}{c}\mathrm{Mn} \\
\left(\mu \mathrm{g} \mathrm{g}^{-1}\right)\end{array}$ & $\begin{array}{c}\mathrm{Cr} \\
\left(\mu \mathrm{g} \mathrm{g}^{-1}\right)\end{array}$ & $\begin{array}{l}\mathrm{Al} \\
\%\end{array}$ & $\begin{array}{l}\mathrm{Fe} \\
\%\end{array}$ & $\begin{array}{c}\mathrm{C}_{\mathrm{org}} \\
\left(\mu \mathrm{g} \mathrm{g}^{-1}\right)\end{array}$ \\
\hline \multicolumn{14}{|l|}{ Core 1} \\
\hline $1 \mathrm{~A}$ & $0-5$ & 13.7 & 0.3 & 0.4 & 22.6 & 18.5 & 17.1 & 54.9 & 61.8 & 32.7 & 2.67 & 1.81 & 29.85 \\
\hline 1B & $5-10$ & 23.7 & 0.7 & 0.4 & 34.1 & 23.2 & 30.1 & 73.8 & 92.6 & 36.1 & 3.07 & 1.65 & 32.26 \\
\hline $1 \mathrm{C}$ & $10-15$ & 16.1 & 0.4 & 0.4 & 29.6 & 26.7 & 25.6 & 72.4 & 138 & 36.5 & 2.91 & 1.90 & 27.61 \\
\hline $1 \mathrm{D}$ & $15-20$ & 15.8 & 0.5 & 0.4 & 40.0 & 21.5 & 34.0 & 78.0 & 111 & 35.4 & 3.49 & 1.87 & 31.09 \\
\hline \multirow[t]{3}{*}{$1 \mathrm{E}$} & $20-25$ & 16.9 & 0.4 & 0.4 & 36.5 & 20.7 & 36.5 & 72.6 & 103 & 48.5 & 4.15 & 1.23 & 36.26 \\
\hline & Media & 17.2 & 0.5 & 0.4 & 32.5 & 22.1 & 28.7 & 70.3 & 101 & 37.8 & 3.26 & 1.69 & 31.41 \\
\hline & $\mathrm{SD}$ & 3.39 & 0.13 & 0.02 & 6.02 & 2.75 & 6.86 & 7.99 & 24.7 & 5.49 & 0.52 & 0.25 & 2.87 \\
\hline \multicolumn{14}{|l|}{ Core 8} \\
\hline $8 \mathrm{~A}$ & $0-5$ & 1.9 & 0.6 & 0.4 & 27.4 & 13.0 & 15.4 & 44.4 & 147 & 45.2 & 1.77 & 1.39 & 26.36 \\
\hline $8 \mathrm{~B}$ & $5-10$ & 13.6 & 0.3 & 0.3 & 30.3 & 21.8 & 13.8 & 53.2 & 144 & 47.1 & 1.95 & 1.38 & 19.71 \\
\hline $8 \mathrm{C}$ & $10-15$ & 12.3 & 0.4 & 0.3 & 20.9 & 17.7 & 19.9 & 42.7 & 158 & 34.5 & 1.69 & 1.41 & 10.46 \\
\hline $8 \mathrm{D}$ & $15-20$ & 7.8 & 0.2 & 0.3 & 15.6 & 17.0 & 19.4 & 55.7 & 109 & 24.4 & 1.34 & 1.26 & 11.61 \\
\hline $8 \mathrm{E}$ & $20-25$ & 4.5 & 0.2 & 0.3 & 22.3 & 22.6 & 14.9 & 41.2 & 136 & 31.9 & 1.59 & 1.50 & 15.75 \\
\hline $8 \mathrm{~F}$ & $25-30$ & 1.9 & 0.3 & 0.2 & 31.1 & 21.4 & 15.0 & 43.3 & 149 & 35.4 & 2.31 & 1.88 & 25.73 \\
\hline $8 \mathrm{G}$ & $30-35$ & 3.4 & 0.3 & 0.2 & 34.2 & 23.5 & 18.1 & 51.1 & 157 & 42.7 & 2.06 & 1.97 & 27.08 \\
\hline \multirow[t]{3}{*}{$8 \mathrm{H}$} & $35-40$ & 3.9 & 0.3 & 0.3 & 23.5 & 21.9 & 20.1 & 56.7 & 100 & 26.2 & 2.20 & 1.45 & 14.10 \\
\hline & Media & 4.3 & 0.3 & 0.3 & 25.3 & 21.3 & 17.5 & 49.6 & 130 & 32.1 & 1.90 & 1.61 & 18.85 \\
\hline & SD & 1.98 & 0.05 & 0.01 & 6.60 & 2.24 & 2.16 & 6.32 & 22.12 & 6.59 & 0.37 & 0.27 & 6.32 \\
\hline \multicolumn{14}{|l|}{ Core 19} \\
\hline $19 \mathrm{~A}$ & $0-5$ & 2.2 & 0.2 & 0.4 & 13.6 & 8.6 & 18.4 & 27.2 & 46.1 & 4.1 & 1.86 & 0.97 & 8.62 \\
\hline 19B & $5-10$ & 4.8 & 0.1 & 0.3 & 13.3 & 10.7 & 19.8 & 32.6 & 34.0 & 4.7 & 1.85 & 0.99 & 22.74 \\
\hline $19 \mathrm{C}$ & $10-15$ & 5.9 & 0.2 & 0.2 & 13.6 & 11.6 & 20.2 & 28.1 & 43.4 & 7.9 & 1.67 & 1.01 & 5.87 \\
\hline 19D & $15-20$ & 8.2 & 0.6 & 0.3 & 21.5 & 14.5 & 21.3 & 39.9 & 36.8 & 10.3 & 2.23 & 0.11 & 17.41 \\
\hline $19 \mathrm{E}$ & $20-25$ & 3.8 & 0.1 & 0.2 & 10.5 & 6.6 & 18.8 & 34.3 & 36.7 & 10.5 & 1.87 & 0.87 & 4.88 \\
\hline $19 \mathrm{~F}$ & $25-30$ & 5.8 & 0.2 & 0.3 & 14.3 & 11.8 & 25.7 & 31.0 & 45.3 & 8.6 & 1.78 & 1.10 & 10.59 \\
\hline $19 \mathrm{G}$ & $30-35$ & 18.0 & 0.4 & 0.3 & 19.9 & 14.2 & 24.4 & 37.4 & 45.6 & 18.4 & 1.91 & 0.99 & 19.30 \\
\hline \multirow[t]{3}{*}{$19 \mathrm{H}$} & $35-40$ & 12.5 & 0.3 & 0.3 & 23.9 & 13.0 & 22.2 & 33.4 & 44.8 & 15.3 & 1.95 & 1.23 & 26.27 \\
\hline & Media & 9.7 & 0.3 & 0.3 & 18.0 & 12.0 & 22.5 & 35.2 & 41.8 & 12.6 & 1.95 & 0.86 & 15.69 \\
\hline & $\mathrm{SD}$ & 5.08 & 0.15 & 0.03 & 4.93 & 2.89 & 2.41 & 3.11 & 4.16 & 3.67 & 0.15 & 0.39 & 7.36 \\
\hline
\end{tabular}

2. The first component $\left(t_{1}\right)$ separated the core 1 fractions (negative part of $\mathrm{t}_{1}$ ) from the core 19 fractions (positive part of $\mathrm{t}_{1}$ ). The fractions located in the negative region of $\mathrm{t}_{1}$ (core 1) show higher contents of $\mathrm{Cu}, \mathrm{Cd}, \mathrm{Ni}, \mathrm{Zn}, \mathrm{Cr}, \mathrm{Al}$ and $\mathrm{C}_{\text {org. }}$. The second component $\left(\mathrm{t}_{2}\right)$ separated the core 8 fractions (negative part of $t_{2}$ ) from the core 1 and 19 fractions (positive part of $\mathrm{t}_{2}$ ). $\mathrm{Mn}$ and $\mathrm{Pb}$ principally contributed to this separation, with the fractions of the negative region of $t_{2}$ showing higher concentrations of $\mathrm{Mn}$ and lower concentrations of $\mathrm{Pb}$.

The organic carbon has a significant participation in the construction of component 1 , evidenced by the association of these variables with the anthropic input due to urban pollution. On the negative side of $t_{1}$, the metal concentration increases and on the negative side of $t_{2}$, the concentration of $\mathrm{Mn}$ increases and $\mathrm{Pb}$ decreases. Therefore, core 1 is mostly distinguished from the others by showing a higher metal average concentration (except $\mathrm{Mn}$ ), associated with a higher anthropic contribution, while the principal characteristics of core 8 are the high $\mathrm{Mn}$ concentrations and lower $\mathrm{Pb}$ concentrations.
Table 2. Principal component (PC) loading of trace metals and sediment properties

\begin{tabular}{lcc}
\hline Variable & $\mathrm{PC}_{1}$ & $\mathrm{PC}_{2}$ \\
\hline $\mathrm{AVS}$ & -0.66 & 0.49 \\
$\mathrm{SEM}$ & -0.67 & 0.27 \\
$\mathrm{Cu}$ & -0.71 & 0.40 \\
$\mathrm{Cd}$ & -0.93 & -0.14 \\
$\mathrm{Ni}$ & -0.81 & -0.40 \\
$\mathrm{~Pb}$ & -0.54 & 0.69 \\
$\mathrm{Zn}$ & -0.92 & 0.04 \\
$\mathrm{Mn}$ & -0.57 & -0.75 \\
$\mathrm{Cr}$ & -0.82 & -0.46 \\
$\mathrm{Al}$ & -0.81 & 0.41 \\
$\mathrm{Fe}$ & -0.64 & -0.55 \\
$\mathrm{C}$ org & -0.84 & 0.09 \\
Proportion of the total variance \% & 56.96 & 19.82 \\
\hline
\end{tabular}

The vertical distribution of AVS and SEM $\left(\Sigma \mathrm{Cd}_{\mathrm{SEM}}+\mathrm{Cu}_{\mathrm{SEM}}+\mathrm{Ni}_{\mathrm{SEM}}+\mathrm{Pb}_{\mathrm{SEM}}+\mathrm{Zn}_{\mathrm{SEM}}\right)$ in the three sediment cores is shown Figure 3. SEM values varied from 0.3 to $0.7 \mu \mathrm{mol} \mathrm{g}^{-1}$ in core 1 , from 0.2 to $0.6 \mu \mathrm{mol} \mathrm{g}^{-1}$ in core 8 and from 0.1 to $0.6 \mu \mathrm{mol} \mathrm{g}^{-1}$ in core 19 . In all three cores 


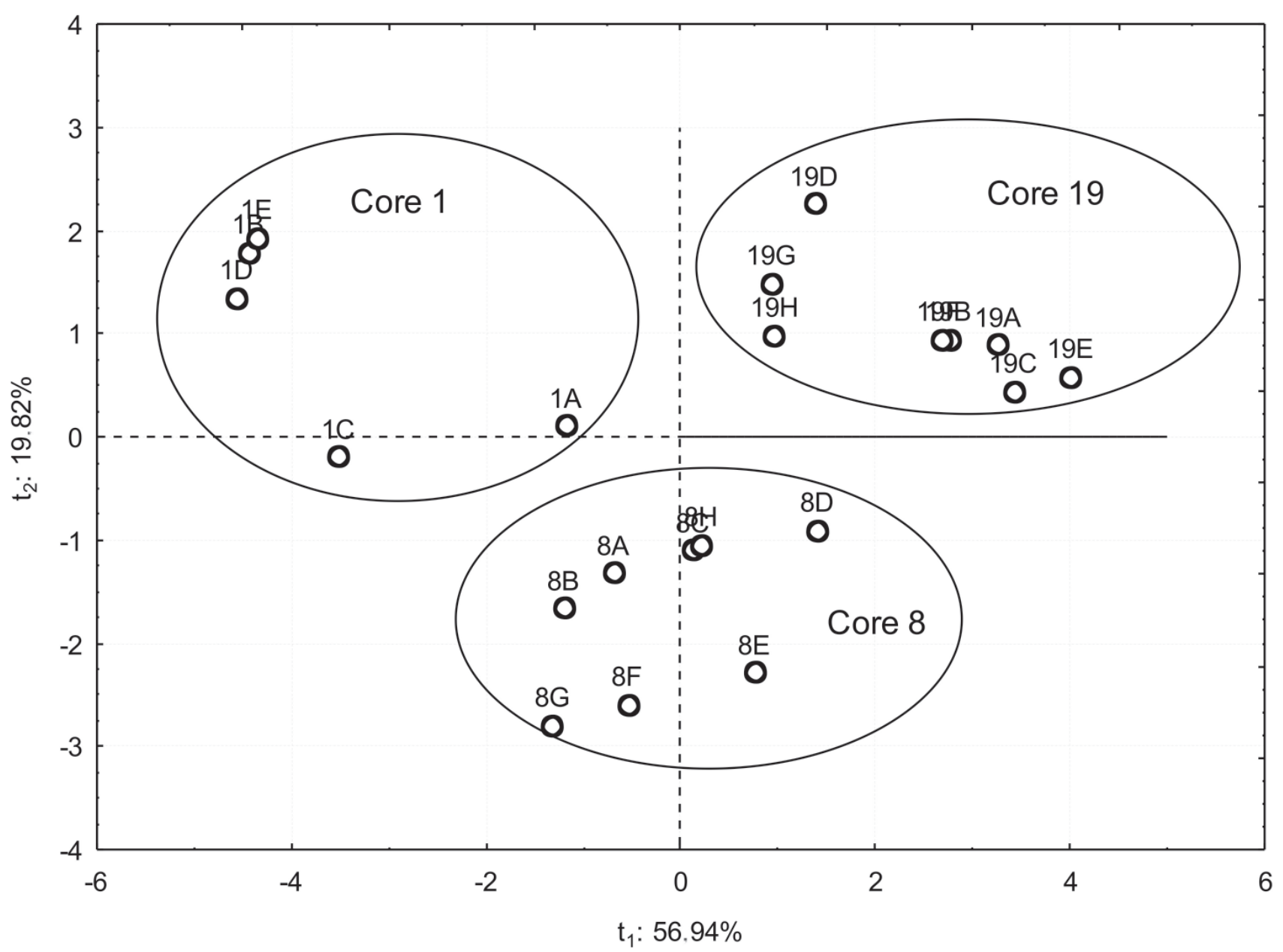

Figure 2. Principal component analysis diagram for the total metal concentrations, AVS, SEM and $\mathrm{C}_{\text {org }}$ of the sediment cores in the Sergipe River Estuary. The fractions of the cores are represented by letters A to $\mathrm{H}$. The groups formed in the analyses are circled.

the concentrations of AVS were higher than the concentrations of SEM, consequently the SEM/AVS relationships were much less than 1 and the SEM-AVS differences less than zero. When the SEM/AVS molar proportions are less than 1 , the concentrations of the metals in the pore water are supposed to be small and non-toxic and, therefore, the sediments should not present acute toxicity for aquatic organisms concerning heavy metal contents. $^{7}$

In core 1, the AVS varied between 13.7 and $23.7 \mu \mathrm{mol}$ $\mathrm{g}^{-1}$, with a peak at $5 \mathrm{~cm}$. In core 8 , the AVS varied between 1.9 and $13.6 \mu \mathrm{mol} \mathrm{g}^{-1}$, with a very low concentration at the surface, a peak at $5-10 \mathrm{~cm}$, and concentrations decreasing gradually down to a depth of $25 \mathrm{~cm}$ and then remaining about constant. In these two cores, the AVS distribution profiles are characterized by peaks a few centimeters beneath the water-sediment interface. These profiles are typical for non-steady depositional processes with instabilities during deposition, such as changes of the size of the particles, in the permeability, porosity etc. ${ }^{13,21}$ In core 1 , the AVS concentrations were higher than in core 8; this difference can be attributed to the higher content of organic matter in the sediments of core 1, caused by the effluent input from the sewage treatment station in that region. The least concentrations in the top layer are due to the transference of $\mathrm{O}_{2}$ from the overlying water to the surface sediments, leading to reduction of the AVS concentration by oxidation. ${ }^{22}$ This profile format was observed in cores of sediments of lake Donghu (China) ${ }^{23}$ and was attributed to the large flow of organic matter to the sediments, originating in domestic and industrial sewage released into the lake. As the generation of AVS occurs through reduction of sulfate to sulfide by sulfate reducing bacteria, and these organisms need carbon for their metabolism, ${ }^{24}$ the presence of large quantities of organic matter potentially contributes to making the sediment anoxic, inhibiting oxidation of AVS in the surface layers. Core 8 was collected in a region of major marine influence and in that region, probably, $\mathrm{SO}_{4}{ }^{2-}$ reduction is more important for AVS formation than the input of 

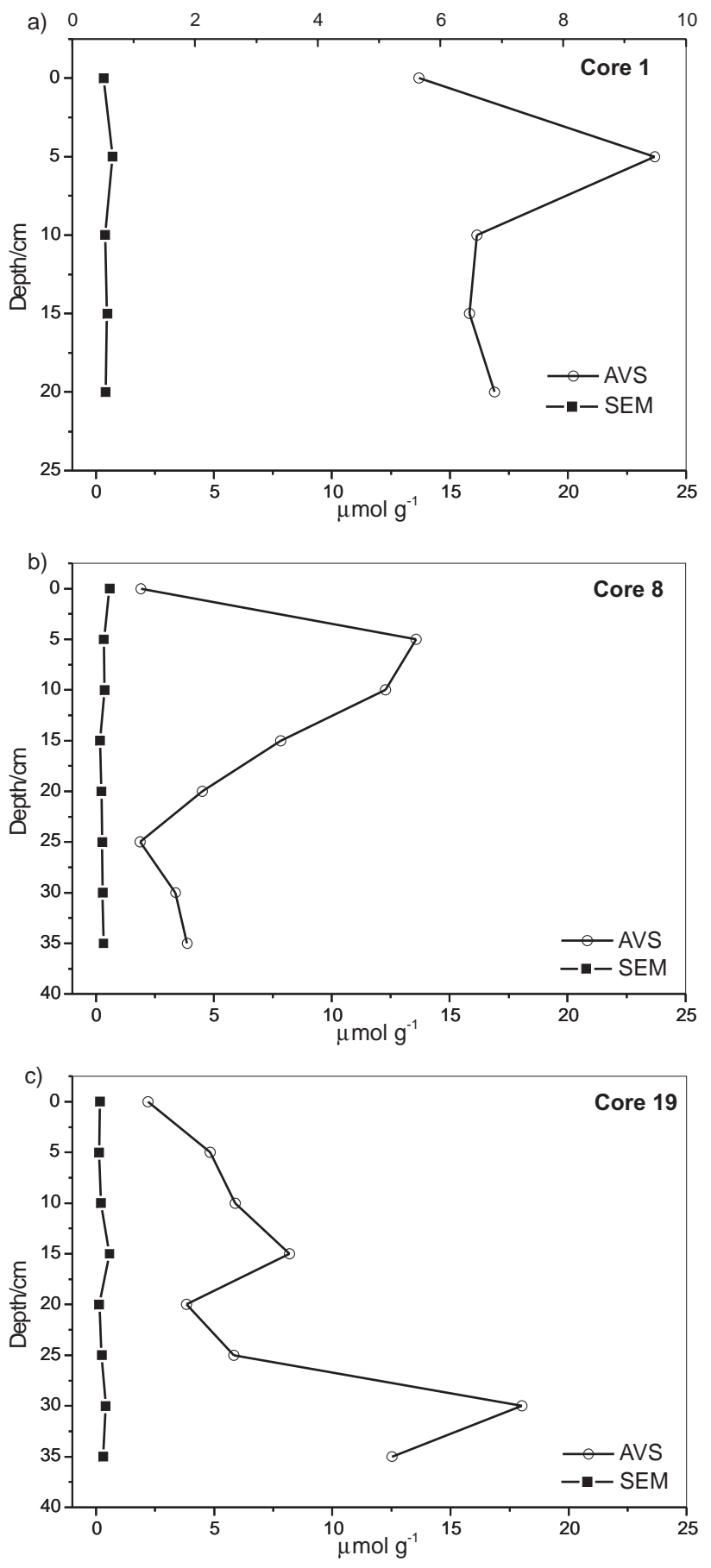

Figure 3. The vertical distribution of AVS and SEM of the sediment cores in the estuarine region formed by the Rivers: (a) Sal - core 1, (b) Sergipecore 8 and (c) Poxim-core 19.

organic matter to the sediment. The high $\mathrm{SO}_{4}{ }^{2-}$ concentrations (20-30 $\left.\mathrm{mmol} \mathrm{L}^{-1}\right)$ in marine sediments, compared with those of the fresh water sediments $\left(0.2 \mathrm{mmol} \mathrm{L}^{-1}\right)$ can account for a greater part of the anoxic oxidation processes in those sediments. ${ }^{31}$

In core 19, the AVS varied between 2.2 and $18.0 \mu \mathrm{mol}$ $\mathrm{g}^{-1}$. The AVS content was lower at the surface and showed an increase along its profile with peaks at 15 and $35 \mathrm{~cm}$. The profile showed a high gradient with a more or less continuous increase in AVS content with depth. In accordance with Van der Berg et al. ${ }^{13}$ this profile indicates a deposition process in steady state with limitations by $\mathrm{SO}_{4}{ }^{2-}$ characterized by a low average deposition rate. Gerritse argues that the low speed of deposition leads to the formation of higher quantities of sulfide in the more anoxic layers, because more sulfate is reduced per unit of depth. ${ }^{25}$ This profile has been reported in distribution studies of AVS in sediments. ${ }^{26-30}$

The first concepts concerning the control and abundance of AVS in anoxic marine sediments were established in the late 1970s. It was observed that in rapidly deposited sediments AVS tends to occur in greater proportion relative to pyrite and that, in sediments which accumulate slowly, AVS is a small fraction of total reduced sulfide (TRS) or even absent, even when pyrite is present in abundance. The low abundance of AVS is due to the rapid and complete transformation of FeS to pyrite in the upper sediment layer. The slow accumulation process favours direct formation of pyrite from $\mathrm{H}_{2} \mathrm{~S}$, which can lead to relatively little AVS. ${ }^{32}$

One of the first studies concerning the behaviour of AVS in marine sediments (Aller, 1977, in Morse and Rickard $^{33}$ ) considers AVS as comprising FeS or a mixture of metastable iron sulfides. Maximum AVS occurs within the zone of greatest TRS formation and coincides with the depth at which dissolved Fe decreases to very low levels and dissolved sulfide increases rapidly. Aller's conclusion is that the reservoir of FeS at any given depth is the result of the balance obtained between the rates of $\mathrm{FeS}$ formation $\left(\mathrm{HS}^{-}\right.$production, and reaction with $\mathrm{Fe}$ ) and loss (conversion to pyrite, oxidation to $\mathrm{Fe}^{3+}, \mathrm{SO}_{4}{ }^{2-}$ ), at that depth.

In a recent review article on AVS Rickard and Morse ${ }^{32}$ cite several studies which used a ${ }^{35} \mathrm{~S}$ tracer to investigate the mechanisms controlling the relationship AVS-pyrite. In the work of Panutrakul et al. ${ }^{34}$ on sediments of the Scheldt estuary in Belgium, using ${ }^{35} \mathrm{SO}_{4}{ }^{2-}$, the main final product was found to be AVS (70-80\%), except in superficial sediments where pyrite and $S^{\circ}$ predominated, indicating the oxidation of sulphide. Close to the surface of sediments $(0-5 \mathrm{~cm})$ AVS constituted around $13 \%$ of TRS, reaching around $30 \%$ in deeper layers. According to Rickard and Morse, ${ }^{32}$ these observations could indicate that in the deeper sediment layers the net sulfide production (formation minus oxidation) is greater than the rate of conversion of AVS to pyrite. Preservation of AVS is favoured by rapid deposition and by low oxygen availability at the sediment-water interface. During rapid 
deposition the sediment is removed rapidly from the zone where most of the oxygen transport via diffusion or bioirrigation occurs.

Table 3 and Figures 4, 5 and 6 show the distributions of the total metals and SEM for the three cores.

In core 1 , the $\mathrm{Cu}, \mathrm{Pb}$ and $\mathrm{Zn}$ profiles are similar and indicate increasing concentrations with depth. Cd showed little variation, with similar concentrations at the different depths. Ni showed an enrichment as far as $10 \mathrm{~cm}$ of depth and then its concentration was reduced, becoming similar to the upper layers.

Core 8 showed similar profiles for $\mathrm{Ni}, \mathrm{Pb}$ e $\mathrm{Zn}$, with a general enrichment of the metals with depth. The $\mathrm{Cd}$ concentration decreased along the profile and the $\mathrm{Cu}$ concentration showed a profile different from the other metals, with peaks at 10 and $40 \mathrm{~cm}$ of depth.

Core 19 showed a general enrichment with depth for $\mathrm{Cu}, \mathrm{Ni}, \mathrm{Pb}$ and $\mathrm{Zn}$ and presented a peak at $15 \mathrm{~cm}$. In spite of $\mathrm{Cd}$ presenting a peak at $15 \mathrm{~cm}$, it did not show any enrichment with depth.

In relatively stable aquatic environments, an enrichment of metals in the surface layer of the sediment is expected as a result of inputs related to industrial activities and urban development. ${ }^{35}$ In the region under study, mainly cores 1 and 19 were obtained from locations that in recent years have shown significant urban and industrial growth. Notwithstanding, in the studied cores enrichment of metals was detected in the surface layer due to the fact that the sediments reflect a non-stable sedimentation process, as a function of the depositional dynamic of the estuarine environments. Similar observations have been made for sediments of the Pearl River in China. ${ }^{14}$

In general, the vertical distribution of the SEM showed for each metal the same distribution trend as that of the total metal. The SEM concentrations for most of the metals represented a relatively large fraction of the total metal concentrations (Figure 7). The highest SEM/metal ratios were shown by $\mathrm{Cd}$ in cores 1 and 8 (from 51 to $97 \%$ of the total $\mathrm{Cd}$ ) and by $\mathrm{Cd}$ and $\mathrm{Zn}$ in core 19 (from 27 to $72 \%$ of the total metal), followed by $\mathrm{Pb}$ in core 8 (from 17 to $59 \%$ ) and $\mathrm{Zn}$ in core 1 (from 26 to $49 \%$ ). In the three cores, the ratios varied from about 6 to $40 \%$, with $\mathrm{Cu}$ presenting lowest ratios (1 to $5 \%$ ). High SEM/metal ratios may indicate that the AVS was the most important phase for the metals in the sediment. The low $\mathrm{Cu}_{\mathrm{SEM}} / \mathrm{Cu}$ ratio was probably due to the metal not being sufficiently soluble in $\mathrm{HCl}$ under the AVS extraction conditions. Some work has shown that $\mathrm{Cu}^{2+}$ is more strongly associated with the organic phase of the sediments and that this can have a minor contribution in the binding of $\mathrm{Cu}^{2+}$ to the sediment. ${ }^{36-38}$

Table 3. AVS, SEM and SEM/AVS ratios of the sediment cores in the estuarine region formed by the Rivers: Sal (core 1), the Sergipe (core 8) and the Poxim (core 19)

\begin{tabular}{|c|c|c|c|c|c|c|c|c|}
\hline $\begin{array}{l}\text { Depth/ } \\
\mathrm{cm}\end{array}$ & $\begin{array}{c}\mathrm{Cd}_{\mathrm{SEM}} / \\
\left(\mu \mathrm{g} \mathrm{g}^{-1}\right)\end{array}$ & $\begin{array}{c}\mathrm{Cu}_{\mathrm{SEM}} / \\
\left(\mu \mathrm{g} \mathrm{g}^{-1}\right)\end{array}$ & $\begin{array}{l}\mathrm{Ni}_{\mathrm{SEM}} / \\
\left(\mu \mathrm{g} \mathrm{g}^{-1}\right)\end{array}$ & $\begin{array}{c}\mathrm{Pb}_{\mathrm{SEM}} / \\
\left(\mu \mathrm{g} \mathrm{g}^{-1}\right)\end{array}$ & $\begin{array}{c}\mathrm{Zn}_{\mathrm{SEM}}{ }^{\prime} \\
\left(\mu \mathrm{g} \mathrm{g}^{-1}\right)\end{array}$ & $\begin{array}{c}\mathrm{S}_{\mathrm{EM}} / \\
\left(\mu \mathrm{mol} \mathrm{g}^{-1}\right)\end{array}$ & $\begin{array}{c}\text { AVS/ } \\
\left(\mu \mathrm{mol} \mathrm{g} \mathrm{g}^{-1}\right)\end{array}$ & SEM/AVS \\
\hline \multicolumn{9}{|l|}{ Core 1} \\
\hline $0-5$ & 0.3 & 0.3 & 7.3 & 5.0 & 11.0 & 0.3 & 13.7 & 0.02 \\
\hline $5-10$ & 0.4 & 0.8 & 5.0 & 7.0 & 36.8 & 0.7 & 23.7 & 0.03 \\
\hline $10-15$ & 0.3 & 0.5 & 2.6 & 2.6 & 20.6 & 0.4 & 16.1 & 0.02 \\
\hline $15-20$ & 0.3 & 0.5 & 5.9 & 4.9 & 22.2 & 0.5 & 15.8 & 0.03 \\
\hline $20-25$ & 0.3 & 0.5 & 4.3 & 4.7 & 19.2 & 0.4 & 16.9 & 0.02 \\
\hline \multicolumn{9}{|l|}{ Core 8} \\
\hline $0-5$ & 0.3 & 0.9 & 5.7 & 9.0 & 15.4 & 0.6 & 1.9 & 0.32 \\
\hline $5-10$ & 0.3 & 0.6 & 5.4 & 7.0 & 12.4 & 0.3 & 13.6 & 0.02 \\
\hline $10-15$ & 0.3 & 1.0 & 4.8 & 8.1 & 14.8 & 0.4 & 12.3 & 0.03 \\
\hline $15-20$ & 0.1 & 0.2 & 2.6 & 3.4 & 7.4 & 0.2 & 7.8 & 0.03 \\
\hline $20-25$ & 0.2 & 0.4 & 3.0 & 5.2 & 9.2 & 0.2 & 4.5 & 0.04 \\
\hline $25-30$ & 0.2 & 0.7 & 3.6 & 7.5 & 10.6 & 0.3 & 1.9 & 0.16 \\
\hline $30-35$ & 0.2 & 0.6 & 3.6 & 7.1 & 11.7 & 0.3 & 3.4 & 0.09 \\
\hline $35-40$ & 0.2 & 0.5 & 2.6 & 4.4 & 16.3 & 0.3 & 3.9 & 0.08 \\
\hline \multicolumn{9}{|l|}{ Core 19} \\
\hline $0-5$ & 0.1 & 0.4 & 1.1 & 1.1 & 8.7 & 0.2 & 2.2 & 0.09 \\
\hline $5-10$ & 0.1 & 0.2 & 0.6 & 0.8 & 7.0 & 0.1 & 4.8 & 0.02 \\
\hline $10-15$ & 0.1 & 0.3 & 1.8 & 1.1 & 11.4 & 0.2 & 5.9 & 0.03 \\
\hline $15-20$ & 0.2 & 0.7 & 3.8 & 6.6 & 29.5 & 0.6 & 8.2 & 0.07 \\
\hline $20-25$ & 0.1 & 0.3 & 0.8 & 1.4 & 7.1 & 0.1 & 3.8 & 0.03 \\
\hline $25-30$ & 0.1 & 0.4 & 1.4 & 2.5 & 13.2 & 0.2 & 5.8 & 0.03 \\
\hline $30-35$ & 0.2 & 0.7 & 3.4 & 3.7 & 20.4 & 0.4 & 18.0 & 0.02 \\
\hline $35-40$ & 0.2 & 0.5 & 2.8 & 3.3 & 14.6 & 0.3 & 12.5 & 0.02 \\
\hline
\end{tabular}



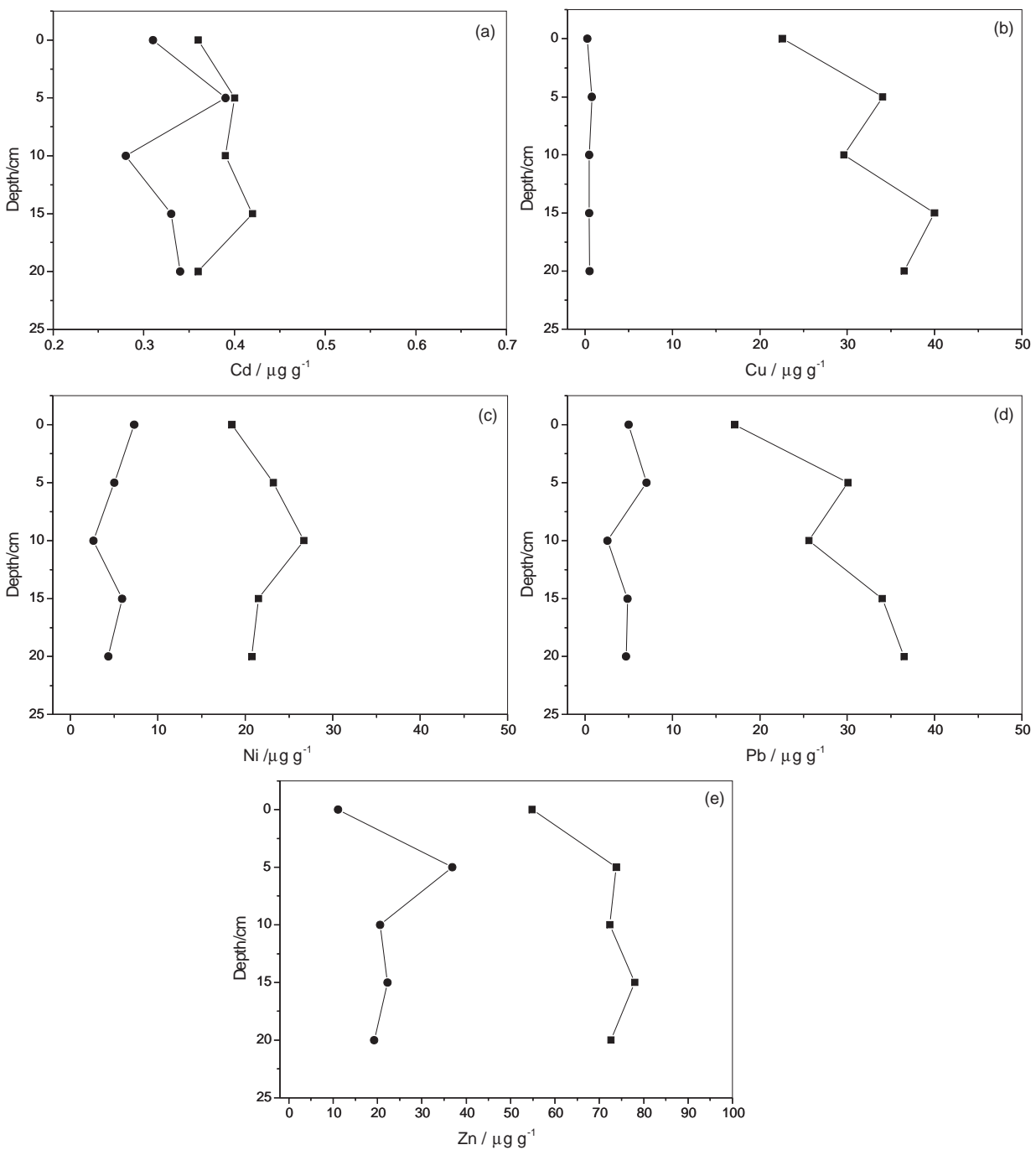

Figure 4. The total and SEM concentrations of (a) $\mathrm{Cd}$, (b) $\mathrm{Cu}$, (c) $\mathrm{Ni}$, (d) $\mathrm{Pb}$ and (e) $\mathrm{Zn}$ in the profile of Core 1, estuarine region of the Sal River metal; $\bigcirc$, SEM).

Peng et al. ${ }^{39}$ detected in studies carried out in the Tuen Mun (Hong Kong) River that $\mathrm{Cd}_{\mathrm{SEM}}$ comprised $81 \%$ of $\mathrm{Cd}, \mathrm{Pb}_{\mathrm{SEM}}$ comprised $76 \%$ of $\mathrm{Pb}$ and $\mathrm{Zn}_{\mathrm{SEM}}$ comprised $67 \%$ of $\mathrm{Zn}$, while $\mathrm{Ni}_{\text {SEM }}$ comprised only $35 \%$ of $\mathrm{Ni}$ and $\mathrm{Cu}_{\text {SEM }}$ comprised only $1.1 \%$ of $\mathrm{Cu}$. Further, they detected that there was a significant correlation between $\mathrm{Cd}_{\mathrm{SEM}}, \mathrm{Pb}_{\mathrm{SEM}}$ and $\mathrm{Zn}_{\text {SEM }}$ and the concentration of the metal in the sulfide phase. This indicates that these metals are more strongly bound to the AVS and this can control the bioavailability of these elements. $\mathrm{Cu}_{\text {SEM }}$ and $\mathrm{Ni}_{\text {SEM }}$ were little soluble in $\mathrm{HCl}$ and were better associated with the organic phase than with the AVS; this phase, better than the sulfide, can control the bioavailability of these metals.

A significant correlation was observed between $\mathrm{Cd}_{\mathrm{SEM}}$ $(\mathrm{r}=0.82), \mathrm{Cu}_{\text {SEM }}(\mathrm{r}=0.95), \mathrm{Pb}_{\text {SEM }}(\mathrm{r}=0.67), \mathrm{Zn}_{\text {SEM }}(\mathrm{r}=0.96)$ and the AVS in core 1 and between $\mathrm{Cd}_{\text {SEM }}(\mathrm{r}=0.67), \mathrm{Cu}_{\text {SEM }}$ $(\mathrm{r}=0.73), \mathrm{Ni}_{\text {SEM }}(\mathrm{r}=0.75), \mathrm{Pb}_{\text {SEM }}(\mathrm{r}=0.52), \mathrm{Zn}_{\text {SEM }}(\mathrm{r}=0.56)$ and the AVS in core 19, evidencing a strong association between the metals and the sulfide in those sediments. The correlation between $\mathrm{Ni}_{\mathrm{SEM}}(\mathrm{r}=0.24)$ and AVS was weak in core 1 suggesting that, in this case, sulfide may not have been an important contributor to binding of the metal in the sediment.

In core 8 , in contrast to the other two cores, no correlation between the AVS and the SME was detected, indicating that in these sediments, sulfide does not seem to be the principal phase of metal-binding. $\mathrm{Cd}_{\mathrm{SEM}}, \mathrm{Ni}_{\mathrm{SEM}}$ and $\mathrm{Pb}_{\text {SEM }}$ presented a moderate correlation with $\mathrm{C}_{\text {org }}(\mathrm{r}=$ 0.35 to 0.59 ). Principal components analysis (Figure 2) demonstrated that the main difference between the sediments of core 8 and the sediments of cores 1 and 19 are the high manganese concentrations. Therefore, it is possible that in core 8 the more important phases of the SEM-binding are associated with the carbonates and the organic matter. Manganese and iron are considered conveyors of trace elements to the sediments by means of 

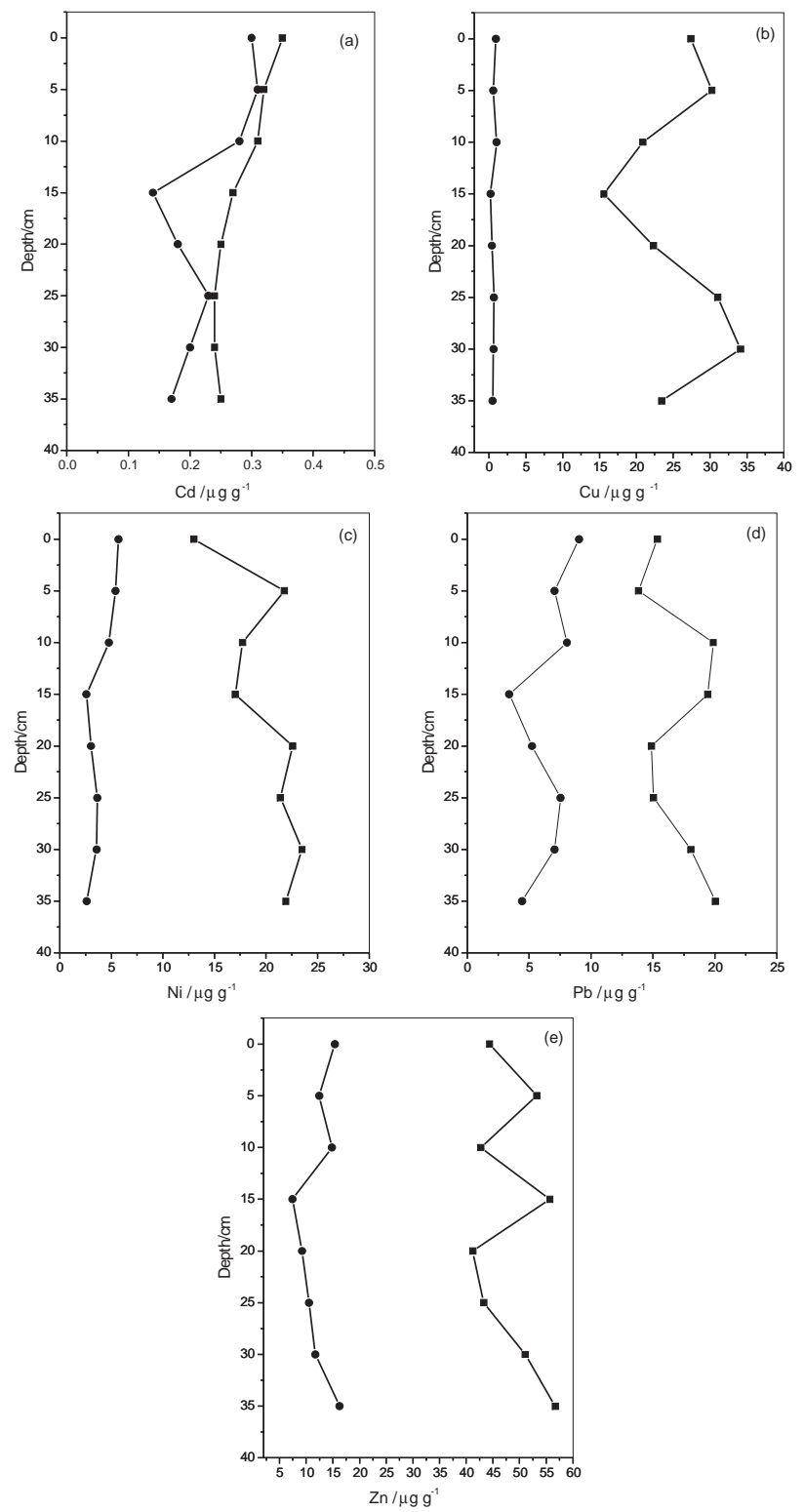

Figure 5. The total and SEM concentrations of (a) $\mathrm{Cd}$, (b) $\mathrm{Cu}$, (c) Ni, (d) $\mathrm{Pb}$ and (e) $\mathrm{Zn}$ in the profile of Core 8, estuarine region of the Sergipe River ( $\mathbf{\square}$, total metal; $\bigcirc$, SEM).

mechanisms such as precipitation (hydroxides, sulfides, carbonates) and adsorption, mainly in the formation of oxides and hydroxides. ${ }^{40-42}$ Much reactive manganese enters the sediments as Mn (IV) oxide, which frequently is reduced in anoxic sediments, before the reduction of the sulfide. This results in the formation of a Mn (II) reservoir, normally associated with the carbonate phase, as rhodocrosite-calcite or dolomite of the Ca-Mn type. So, much reduced manganese cannot be available for the formation of mineral sulfide. ${ }^{43-45}$

Yu et al. ${ }^{46}$ when studying the spatial distribution of the AVS and SEM in sediment cores of the Ell-Ren River (Taiwan), detected the existence, besides AVS, of other
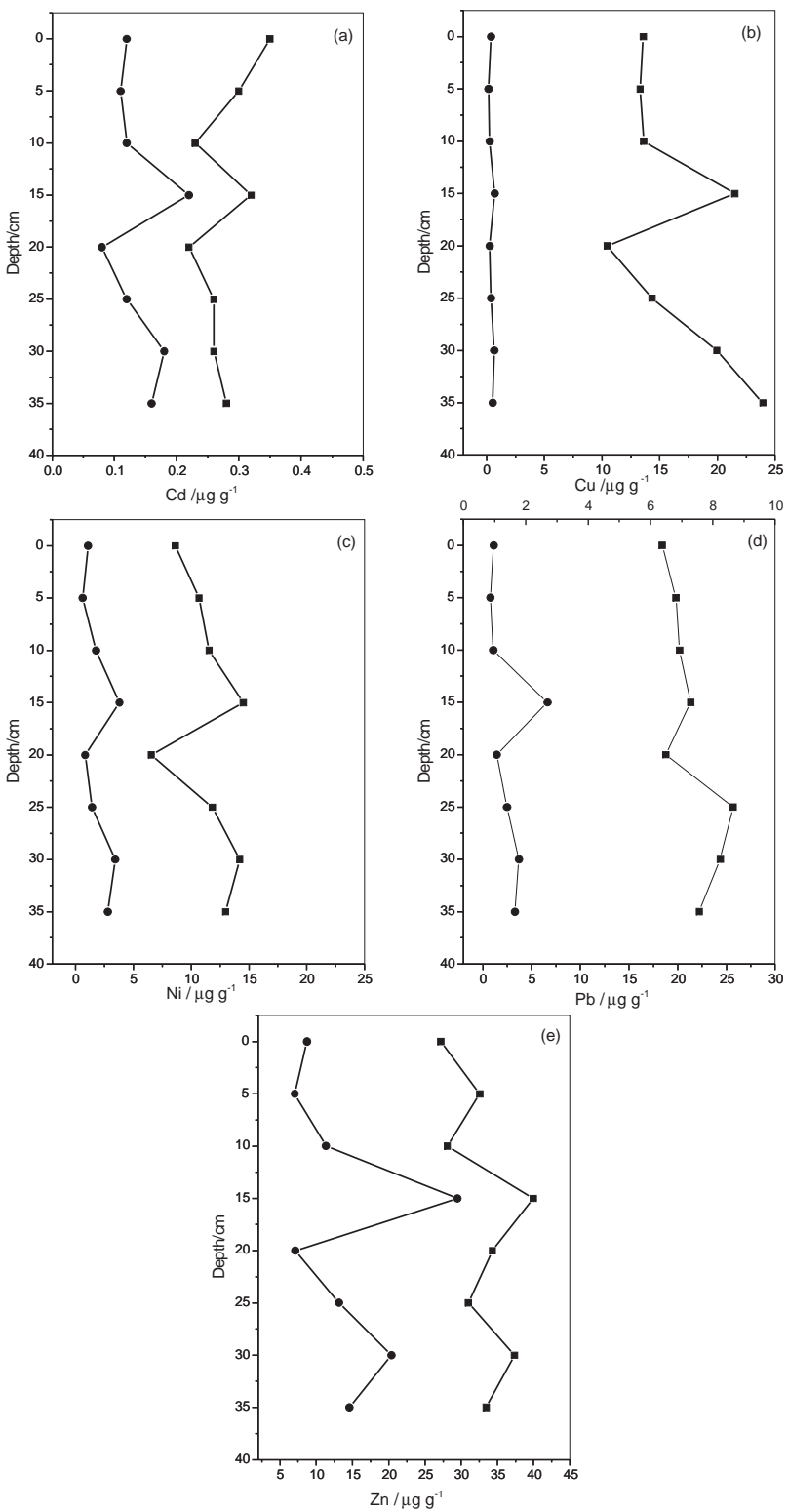

Figure 6. The total and SEM concentrations of (a) $\mathrm{Cd}$, (b) $\mathrm{Cu}$, (c) $\mathrm{Ni}$, (d) $\mathrm{Pb}$ and (e) $\mathrm{Zn}$ in the profile of Core 19, estuarine region of the Poxim River ( $\mathbf{\square}$, total metal; $\bigcirc$, SEM).

binding phases for the SEM, that is, the total concentration of the SEM does not correspond only to the metals bound to AVS. Comparing the spatial distribution of the SEM/AVS relationship with several binding phases in extremely anoxic sediments (redox potential between -115 and $-208 \mathrm{mV}$ ), they concluded that the organic phases and the carbonates were, after the AVS, the principal binding phases for the SEM. They also observed that in slightly anoxic sediments (redox potential between -50 and $-130 \mathrm{mV}$ ), the iron oxides were the additional principal phase for zinc and the organic matter for copper. In all cases, the AVS seemed to have binding priority for the SEM. 

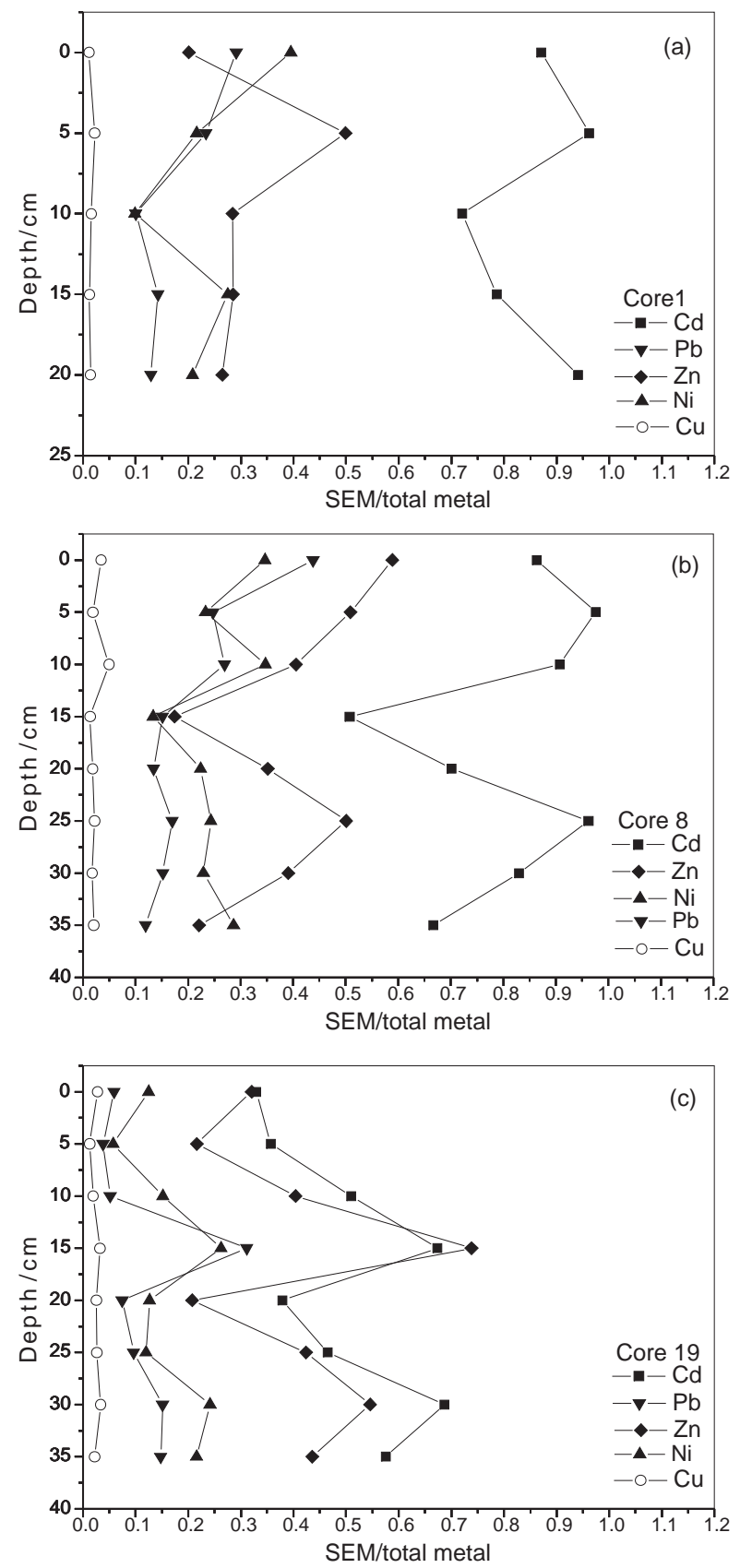

Figure 7. The ratio of SEM/total metal of the sediment cores in the estuarine region formed by the Rivers: (a) Sal - core 1, (b) Sergipe - core 8 and (c) Poxim - core 19. ( $\mathbf{\square}, \mathrm{Cd}$; O, $\mathrm{Cu} ; \boldsymbol{\Lambda}, \mathrm{Ni} ; \boldsymbol{\nabla}, \mathrm{Pb}$;, $\mathrm{Zn}$ ).

AVS was not the most important binding phase for the metals in surface sediments of the Pearl River Estuary and therefore the SEM may contain different chemical forms of the trace elements, depending on the reaction of the metal with cold $\mathrm{HCl}^{14}$

Therefore, the results stress the need of carrying out sequential extraction for a better understanding of SEM and its association with the different geochemical phases of the sediment, even when the concentration of AVS is high and greater than that of SEM.

\section{Conclusions}

This study presents trace metals, AVS and SEM profiles in sediment cores taken at different locations in an estuarine system formed by the Sal river (core 1), Sergipe river (core 8) and Poxim river (core 19). Multivariate statistical analysis, applied to the full dataset, allowed distinctions to be made between the different cores. Core 1 is mainly distinguished from the others by showing higher average metal concentrations (except $\mathrm{Mn}$ ), associated with a higher anthropic contribution, while the principal characteristics of core 8 are the high $\mathrm{Mn}$ concentrations and lower $\mathrm{Pb}$ concentrations.

Based on the AVS profiles in each core, two types of sedimentation processes were identified, a non-steady process with instabilities during deposition (cores 1 and 8) and a depositional process in steady state characterized by a low average deposition rate (core 19). Preservation of AVS is favoured by low oxygen concentrations in the overlying water.

In the sediments from the estuarine region of the Sal and Poxim Rivers, the sulfide seems to be the principal metal-binding phase, while in the region of the Sergipe river the most important metal-binding phase seems to be associated with the organic mater and the carbonates. The elevated concentrations of manganese in sediments from the Sergipe river region could have resulted in formation of a large sink reservoir of $\mathrm{Mn}(\mathrm{II})$, associated with the carbonates phase. In all three cores, SEM/AVS ratios were much less than 1 .

\section{Acknowledgments}

The authors gratefully acknowledge Dr. Andrew Allen (University of Birmingham) for his assistance with the English in this manuscript and CNPq (Process 620065/ 2004-4) and FINEP (Process 0828/03) for financial support of this study.

\section{References}

1. Manahan, S. E.; Environmental Chemistry, $6^{\text {th }}$ ed., Lewis Publishers: New York, 1999.

2. Lee, J. S.; Lee, J. H.; Sci. Total Environ. 2005, 338, 229.

3. Di Toro, D. M.; Mohony J. D.; Hansen D. J.; Scott K. J.; Hicks M. B.; Mayr S. M.; Redmond M. S.; Environ. Sci. Technol. 1990, 9, 1489.

4. Ankley, G. T.; Phipps, G. L.; Leonard, E. N.; Kosian, P. A.; Cotter, A. M.; Dierkes, Jr.; Environ. Toxicol. Chem. 1991, 10, 1299. 
5. Berry, W. J.; Hansen, D. J.; Mahony, J. D.; Robson, D. L.; Di Toro, D. M.; Shipley, B. P.; Rogers, B.; Corbin, J. M.; Boothman, W. S.; Environ. Toxicol. Chem. 1996, 15, 2067.

6. Hansen, D. J.; Berry, W. J.; Mahony, J. D.; Boothman, W. S.; Di Toro, D. M.; Robson, D. L.; Environm. Toxicol. Chem. 1996, 15, 2080.

7. Di Toro, D. M.; Mahony, J. D.; Hansen, D. J.; Scott, K. J. ; Carlson, A. R.; Ankley, G. T.; Environ. Sci. Technol. 1992, 26, 96.

8. Lee, B. G.; Griscom, S. B.; Lee, J. S.; Choi, H. J.; Koh, C. H.; Luoma, S. N.; Fisher, N. S.; Science. 2000, 287, 282.

9. Brumbaugh, W. G.; Ingersoll, C. G.; Kemble, N. E.; May, T. W.; Zajicek, J. L.; Environ. Toxicol. Chem. 1994, 13, 1971.

10. Dornblaser, M., Giblin, A. E., Fry, BH., Peterson, B. J.; Biogeochem. 1994, 24, 129.

11. Urban, N. R., Brezonik, P. L., Baker, L. A., Sherman, L. A.; Limnol. Oceanogr. 1994, 39, 797.

12. Berner, R. A.; Early Diagenesis: A Theoretical Approach, Princeton University Press: Princeton, 1980, NJ, USA.

13. Van den Berg, G. A.; Buykx, S. E. J.; Van den Hoop, M. A. G. T.; Van der Heijdt, L. M.; Zwolsman, J. J. G.; Appl. Geochem. 2001, 16, 781.

14. Fang, T.; Lia, X; Zhang, G.; Ecotoxicol. Environ. Saf. 2005, $61,420$.

15. Oehm, N. J.; Luben, T. J.; Ostrofsky, M. J.; Hydrobiology 1997, $345,79$.

16. JICA. Japan International Cooperation Agency. 2000. The study on water resources development in the state of Sergipe in the Federative Republic of Brazil - Main Report. 406p.

17. Passos, E. A.; Barbieri, E.; Garcia, C. A. B.; Alves, J. P. H.; $O$ Mundo da Saúde. 2005, 29, 225.

18. Berner, R. A.; Am. J. Science. 1967, 265, 773.

19. Allen, H. E.; Fu, G.; Deng, B.; Environ. Toxicol. Chem. 1993, $12,1441$.

20. Lasorsa, B.; Casas, A.; Mar. Chem. 1996, 52, 211.

21. Matisoff, G.; Holdren, G. R.; Water Resour. Res. 1995, 31, 1751.

22. Song, Y. S.; Müller, G.; Sediment-Water Interactions in Anoxic Freshwater Sediments-Mobility of Heavy Metals and Nutrients, Springer: Berlin, 1999.

23. Zheng, L; Xu, X. Q; Xie, P.; Bull. Environ. Contam. Toxicol. 2004, 72, 326.
24. Oenema, O.; Biogeochem. 1990, 9, 75.

25. Gerritse, R. G.; Appl. Geochem. 1999, 14, 41.

26. Howard, D. E.; Evans, R. D.; Environ. Toxicol. Chem. 1993, 12, 1051 .

27. Leonard E. N.; Mattson V. R.; Benoit D. A.; Hoke R. A.; Ankley G. T.; Hydrobiologia. 1993, 271, 87.

28. Makley, A. P.; Mackay, S.; Environ. Pollut. 1996, 93, 205.

29. Besser, J. M.; Ingersoll, C. G.; Giesy, J. P.; Environ. Toxicol. Chem. 1996, 15, 286.

30. Van den Berg, G. A.; Loch, J. P. G.; Van der Heijdt, L. M.; Zwolsman, J. J. G.; Environ.Toxicol. Chem. 1998, 17, 758.

31. Balzer, W.; PhD Thesis; Habilitationsschrift Universität Kiel. 1989, 312S

32. Rickard, D.; Morse, J.; Mar. Chem. 2005, 97, 141.

33. Morse, J.; Rickard, D.; Environ. Sci. Technol. 2004, 1, 131A.

34. Panutrakul, S.; Monteny, F.; Baeyens, W.; Estuaries 2001, 24, 257.

35. Li, X. D.; Wai, O. W. H.; Li, Y. S.; Coles, B. J.; Ramsey, M. H.; Thornton, I.; Appl. Geochem. 2000,15, 567.

36. Campbell, A. C.; Gieskes, J. M.; Lupton, J. E.; Lonsdale, P. F.; Geochim. Cosmochim. Acta 1988, 52, 345.

37. Cooper, D. C.; Morse, J. W.;. Environ. Sci. Technol. 1998, 32 , 1076.

38. Ngiam, L-S; Lim, P-E.; Sci. Total Environ. 2001, 275, 53.

39. Peng, S. H.; Wang, W. X.; Li, X., Yen, Y. F.; Chemosphere 2004, 57, 839.

40. Salomons, W; Fortner, U.; Metal in the Hidrocycle, Spring Verlager: Berlin, Heidelberg, 1984, p439.

41. Feely, R. A.; Massoth, G. J.; Paulson, A. J.; Gendron, G. F.; Estuar. Coast. Shelf Sci. 1983, 17, 693.

42. Calvert, S.E.; Price, N.B.; Mar. Chem. 1997, 5, 43.

43. Böttcher M. E.; Mar. Chem. 1998, 62, 287.

44. Mucci. A.; Geochim. Cosmochim. Acta 1988, 52, 1859.

45. Morse, J. W.; Luther, G. W.; Geochim. Cosmochim. Acta 1999, 63, 3373.

46. Yu, K. C.; Tsai, L. J.; Chen, S. H.; Ho, S. T.; Water Res. 2001, $35,4086$.

Received: June 16, 2006

Web Release Date: June 29, 2007 